\title{
Estimating the most effective and economical pheromone for monitoring the European spruce bark beetle
}

\author{
Nina Šramel ${ }^{1}$ (D) | Andreja Kavčič ${ }^{1}$ (D) | Marija Kolšek ${ }^{2}$ | Maarten $\operatorname{de~Groot~}^{1}$ (D)
}

\author{
${ }^{1}$ Slovenian Forestry Institute, Ljubljana, \\ Slovenia \\ ${ }^{2}$ Slovenia Forest Service, Ljubljana, Slovenia

\section{Correspondence} \\ Maarten de Groot, Slovenian Forestry \\ Institute, Večna pot 2, 1000 Ljubljana, \\ Slovenia. \\ Email: maarten.degroot@gozdis.si

\section{Funding information} \\ Javna Agencija za Raziskovalno Dejavnost \\ RS, Grant/Award Number: V4-1822
}

\begin{abstract}
In recent decades, there have been an increasing number of outbreaks of Ips typographus in Europe. A large amount of sanitary felling has taken place, with significant economic and ecological consequences. In order to anticipate such large-scale outbreaks, an effective monitoring system should be set up. One important aspect of monitoring is deciding which pheromone to use. Therefore, we decided to test five different commercially available pheromone lures under different disturbance conditions: Pheroprax $₫$, IT Ecolure Extra ${ }^{\circledR}$, Ipstyp $\AA$, Ipsowit $₫$ and Typosan $₫$. We investigated the ability of the pheromones to distinguish between disturbed and undisturbed locations, their cost-efficiency ratio, and side effects such as bycatch abundance and composition. We set 50 traps in two areas with sites that were disturbed and undisturbed by windstorms. We collected the catch from traps every 1-2 weeks from the end of March until the end of September in 2019. We found that IT Ecolure Extra $\AA$, Ipsowit $\AA$ and $\AA$ Pheroprax $\AA$ caught the most $I$. typographus and best showed changes in the trap catch of $I$. typographus throughout the whole season. There was a low amount of bycatch ( $<6 \%$ of the total catch) and a low number of predators (a few specimens), but some groups seem to prefer certain pheromones. The cost of the pheromones increased with their effectiveness. However, pheromone costs are low relative to the personnel costs involved in setting traps and collecting the catch. Based on all of the gathered data, we created an index which helps to assess the cost-efficiency of the five chosen commercially available pheromones. We also present guidelines on how to make such an index to assist other researchers in choosing the right pheromone for monitoring populations of $I$. typographus or other bark beetle species.
\end{abstract}

KEYWORDS

bark beetles, cost-efficiency, Ips typographus, monitoring, pheromones, Picea abies

\section{1 | INTRODUCTION}

Climate change has strong effects on forests and all their functions

(Lindner et al., 2010; Sturrock et al., 2011). In recent years, conditions have been favourable for the spread of forest pests and diseases, which has resulted in large-scale tree dieback and other negative effects on forest ecosystems (de Groot \& Ogris, 2019; Seidl et al., 2017; Sturrock et al., 2011). In addition, increasing temperatures and

This is an open access article under the terms of the Creative Commons Attribution-NonCommercial License, which permits use, distribution and reproduction in any medium, provided the original work is properly cited and is not used for commercial purposes.

(c) 2021 The Authors. Journal of Applied Entomology published by Wiley-VCH GmbH. 
associated extreme climatic events such as windthrows, droughts and ice storms have impacted the health of trees and forests (de Groot et al., 2018; Nagel et al., 2017; Seidl et al., 2017; ZGS, 2019a, $2019 b)$, with large-scale outbreaks of forest pests as a cascading effect (Buma, 2015; de Groot et al., 2018; Raffa et al., 2008). These large-scale outbreaks have significant economic consequences, and it is therefore important to find methods to respond to them as soon as possible. However, the response should not be overly expensive or have a large impact on the environment (Lewis et al., 1997).

The European spruce bark beetle (Ips typographus (L.), Coleoptera: Curculionidae, Scolytinae) has been one of the most problematic forest pests in Central Europe in the last decades (Vité, 1989; Wermelinger, 2004). The increasing frequency of catastrophic climatic events, inappropriate forest management (Bončina et al., 2017; de Groot et al., 2019) and monocultures have led to more frequent and severe outbreaks (de Groot et al., 2019; Potterf et al., 2019; Wichmann \& Ravn, 2001). In Slovenia, one of the most noticeable changes was afforestation with $P$. abies for the timber industry in the 19th and in the 20th century. Unfortunately, the planting of Norway spruce trees (Picea abies) in new habitats, in most cases at lower altitudes, resulted in lower viability (Levanič et al., 2009). One of the negative consequences of this was a rise in I. typographus infestations (Ogris \& Jurc, 2010). According to the work of de Groot et al. (2019), in the period from 1996 to 2017, in natural or unchanged forests with a median $P$. abies growing stock of $5.61 \%$, the median sanitary felling because of I. typographus was $0.025 \mathrm{~m}^{3} \mathrm{ha}^{-1} \mathrm{year}^{-1}$, while in highly changed forests, the median sanitary felling increased to $0.26 \mathrm{~m}^{3} \mathrm{ha}^{-1} \mathrm{year}^{-1}$. Additionally, droughts and increasing temperatures indirectly worsen outbreaks by weakening P. abies and accelerating the development of I. typographus (de Groot \& Ogris, 2019; Netherer et al., 2019). The most effective way to deal with these outbreaks is to radically change forest management, but in cases of catastrophic climatic events, this is not possible, and an ad hoc response should be devised as well as an early warning system for I. typographus outbreaks. In such a system, early warning consists of a short-term forecasting system which predicts the risk areas in the next year (de Groot \& Ogris, 2019). Furthermore, the development of the life history stages of I. typographus should be modelled in order to predict the timing of outbreaks, timing of swarming and, therefore, the timing of the placement of the pheromone traps (Baier et al., 2007; Ogris et al., 2019). In Europe, the monitoring of I. typographus outbreaks consists of pheromone traps, trap logs or field assessments of trees (Fettig \& Hilszczański, 2015; Wermelinger, 2004), all of which have their pros and cons. Trap logs and field assessments are time-consuming and require a large number of people, and they can only cover a relatively small surface. Pheromone traps can cover a large area, but after windthrows, the volatiles emitted by fallen trees can override the attractiveness of the pheromone used in the traps (Lobinger, 1995; Wermelinger, 2004). It is therefore important to find a pheromone that maintains its attractiveness under all disturbance regimes.
In other words, a framework should be developed to decide which pheromone should be used for sustainable management. The first step would be to assess the effectiveness of the pheromone in attracting $I$. typographus and how the trap catch changes over the year. The next step would be to determine the cost of the pheromone and the monitoring system, as well as its influence on the bycatch. Taking the bycatch into account might become even more important in the future because in recent years, a marked decrease in different insect species has been recorded around the world (Hallmann et al., 2017; Sánchez-Bayo \& Wyckhuys, 2019), including in forest ecosystems (Seibold et al., 2019). There is also growing concern over population decreases in many beneficial insect species which control populations of pests (Ryall \& Fahrig, 2005), and for this reason, some modifications have already been made to lower the bycatch of I. typographus predators (Martín et al., 2013). Monitoring systems, therefore, should minimize the negative effect on populations of beneficial insects and other insect diversity. A good pheromone should be effective in recording I. typographus under all situations, and as pointed out earlier, it should be relatively cheap and should not affect insect diversity, especially that of beneficial insects.

The aim of this study was to prepare an index in order to determine the most effective and economical pheromone for the monitoring of I. typographus. We tested five different commercially available pheromones in the field under undisturbed and disturbed conditions. We prepared a standardized index to compare the efficiency, sensitivity and bycatch to the pheromone costs, and we set out to determine (i) whether the pheromones differ in terms of their trapping efficiency of I. typographus in different situations, (ii) whether they differ in terms of the bycatch in different situations and (iii) what proportion of the total cost of monitoring is represented by the cost of the pheromones. We hypothesized that (i) the most expensive pheromone might not be the most efficient; (ii) the pheromone with the highest catch rate would also be the one that shows the greatest difference between disturbed and undisturbed locations; (iii) in the case of bycatch and predators, the catch pattern would be similar to that of I. typographus for each type of pheromone; (iv) the species composition between the pheromones would be different; ( $v$ ) the bycatch composition would be different for each pheromone; and (vi) the cost of pheromones represents a significant share of the total cost of monitoring.

\section{2 | MATERIALS AND METHODS}

\section{1 | Area description}

Slovenia is a geographically diverse country with the Alps in the north, the Dinaric Mountains in the south, the Pannonian Plain in the east and the Mediterranean region in the west. Altitude ranges from 0 to 2,864 $\mathrm{m}$ (Kozjek et al., 2017). It is one of most forested European countries. In 2018, forests covered $58.1 \%$ of 
the surface or $1,193,750$ ha. Currently, the share of the growing stock of deciduous trees is $55.1 \%$, and the share of coniferous trees is $44.9 \%$, the majority of which consists of Norway spruce (P. abies) (ZGS, 2019a).

The study took place in two areas: the Kranj forest management area (FMA) (X: 455,736, Y: 138,421) and the Slovenj Gradec FMA (X: 513,997, Y: 150,761). The Kranj FMA is located in the Alpine and sub-Alpine region of the middle northwest part of Slovenia, with an altitude ranging from $320 \mathrm{~m}$ to $2,558 \mathrm{~m}$. The area encompasses 107,641 ha, of which $67 \%$ is forested. The soil base consists mainly of dolomite and limestone. The area experiences a mixture of the temperate Alpine and humid continental climates (ZGS, 2012a). The Slovenj Gradec FMA is located in the Alpine and Dinaric-Pannonian region of the middle northeast part of Slovenia, with an altitude ranging from $320 \mathrm{~m}$ to $2,128 \mathrm{~m}$. The area encompasses 88,828 ha, of which $68 \%$ is forested. The soil base is silicate. The area experiences a mixture of the Alpine and Pannonian climates (ZGS, 2012b).

\subsection{Experimental design and survey protocol}

The experiment was carried out in 2019, from late March until the end of September. Even though Slovenia has a high percentage of forest, its patchiness presents challenges for field experiments. Our desired working area was a combination of two locations: (i) a disturbed location which was affected by windthrow in the previous year and (ii) an undisturbed location which was not affected by windthrow. For both locations, some of the parameters had to be the same: the population of I. typographus had to be below the multiplication threshold, the share of Norway spruce ( $P$. abies) had to be $70 \%$ or more of the growing stock, other ecological conditions had to be comparable (tree composition, altitude, slope, insolation, average monthly air temperature, average monthly rainfall) and the locations had to be big enough to make it possible to set up five repetitions of each pheromone in both locations. To fulfil our conditions, it was necessary to use two areas: the Slovenj Gradec FMA and the Kranj FMA. For each FMA, we selected one area as a disturbed location (Slovenj Gradec for the Slovenj Gradec FMA and Jezersko for the Kranj FMA) and one area as an undisturbed location (Mislinja for the Slovenj Gradec FMA and Tržič for the Kranj FMA). In total, we used 50 single Theysohn slit traps and five different commercially available pheromones: IT Ecolure Extra ${ }^{\circledR}$, Typosan $\AA$, Ipstyp $\AA$, Ipsowit $\AA$ and Pheroprax ${ }^{\circledR}$ (Table 1). Since we had to divide five repetitions per treatment (disturbed and undisturbed), we set up 30 traps in the Slovenj Gradec FMA and 20 traps in the Kranj FMA. The altitude of the traps in the Slovenj Gradec FMA ranged from $468 \mathrm{~m}$ to $1,275 \mathrm{~m}$ for the Slovenj Gradec location and from $666 \mathrm{~m}$ to $1,046 \mathrm{~m}$ for the Mislinja location. The minimum distance between the disturbed and undisturbed location was approximately $3.5 \mathrm{~km}$. In each trap, there was only one pheromone, and there were three repetitions of each pheromone per location. The altitude of the traps in the Kranj FMA ranged from $883 \mathrm{~m}$ to $1,073 \mathrm{~m}$ for the Jezersko location and from $899 \mathrm{~m}$ to $1,111 \mathrm{~m}$ for the Tržič location. The minimum distance between the disturbed and undisturbed locations was approximately $6.5 \mathrm{~km}$. In each trap, there was only one pheromone, and there were two repetitions of each pheromone per location. Traps were distributed randomly and evenly across the selected locations, and each trap was at least $1 \mathrm{~km}$ away from adjacent traps. The pheromones were changed by the Slovenia Forest Service (SFS) depending on temperature and an assessment of the pheromones in the field; thus, the pheromones were changed every 30-50 days in the Kranj FMA and every 60-70 days in the Slovenj Gradec FMA.

Traps were set up at the end of March (28.3.2019, Mislinja) or at the beginning of April (2.4.2019, Slovenj Gradec; 4.4.2019, Jezersko; 9.4.2019, Tržič). Traps were emptied every seven to 14 days, depending on the temperature. If the temperature was higher than $24^{\circ} \mathrm{C}$, it was mandatory to empty the traps every seven days. The catch was collected into plastic pots and marked with the trap ID and date of collection. All samples were delivered to the Slovenian Forestry Institute Department of Forest Protection and placed into a refrigerator until morphological analysis. All collections were carried out by district foresters of the SFS.

The morphological analysis was done in the laboratory with the help of a stereomicroscope and identification keys. First, we separated all specimens of I. typographus, counted them when the number of specimens was low and measured their volume when counting

\begin{tabular}{|c|c|c|c|c|}
\hline Pheromone & Producer & Composition & Type & $\begin{array}{l}\text { Time of } \\
\text { efficacy }\end{array}$ \\
\hline Pheroprax $®$ & BASF & $\begin{array}{l}\text { S-Ipsdienol } \\
\text { S-cis-Verbenol } \\
\text { 2-metil-3-buten-2-ol }\end{array}$ & ampoule & 8-12 weeks \\
\hline Typosan® & Sintagro AG & $\begin{array}{l}\text { S-cis-Verbonol } \\
\text { 2-metil-3-buten-2-ol }\end{array}$ & blotter & 8-12 weeks \\
\hline 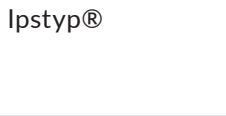 & AlphaScents Inc. & $\begin{array}{l}\text { S-Ipsdienol } \\
\text { S-cis-Verbenol } \\
\text { 2-Methyl-3-buten-2-ol }\end{array}$ & blotter & 6 weeks \\
\hline Ipsowit $®$ & Witasek & $\begin{array}{l}\text { S-Ipsdienol } \\
\text { S-cis-Verbenol }\end{array}$ & blotter & $6-8$ weeks \\
\hline IT Ecolure Extra $®$ & Fytofarm & S-cis-Verbenol & blotter & 6-8 weeks \\
\hline
\end{tabular}

TABLE 1 Name of used commercially available pheromones, their producer, composition, type and time of efficacy specified by the manufacturer 
was too time-consuming $(1 \mathrm{ml}$ equals 40 specimens of I. typographus). The Coleoptera bycatch was determined to the family level. Only predators of $I$. typographus were determined to the species level if possible (Thanasimus sp., Thanasimus femoralis, Thanasimus formicarius and Nemosoma elongatum). Other taxa in the bycatch were determined to the order level.

\section{3 | Statistical analysis}

The data were condensed to the trap level for comparison between pheromones, FMA and type of disturbance (disturbed/undisturbed). All specimens of I. typographus and bycatch collected over the year per trap were summed for all 50 traps. The bycatch was separated into the total number of specimens, the specimens per beetle family and the number of I. typographus predators from the Coleoptera family.

For differences in catch effectiveness and bycatch, we used the general linear model (GLM) method using a negative binomial error distribution. For predators, there were many zeros in the data set; therefore, a hurdle model, which is divided into a binomial model and a truncated Poisson model (Zuur et al., 2009), was used. For effectiveness, the dependent variable was the number of I. typographus caught during the whole season. For the bycatch, the dependent variable was the number of specimens other than I. typographus. For predators, the dependent variable was the number of specimens of predators of $I$. typographus (Thanasimus femoralis, Thanasimus formicarius and Nemosoma elongatum). The independent variables were the type of pheromone, type of disturbance and FMA (Slovenj Gradec and Kranj). All of the different models were built from a model including all independent variables and the interaction between disturbance and pheromones. These models were compared with the help of the Akaike Information Criterion (AIC) (Burnham $\&$ Anderson, 2004). The model with the lowest AIC was the best model. When more models were within 2 AIC units from the best model, the model with the least variables was selected as the best model. For the number of bycatch and I. typographus predators, the same approach was taken as that for catch effectiveness. For this analysis, the statistical program R was used (R Core Team, 2018).

The changes in trap catch throughout the season of I. typographus were investigated with a generalized additive model with a Poisson error distribution. The dependent variable was the number of $I$. typographus per day per catch period. The analysis involved two steps: first, the difference in phenology was checked for the different FMAs, and then the difference in phenology for the pheromones was checked per FMA. The model selection was done on the basis of the AIC. For the analysis with the GAM, the library 'mgcv' was used (Wood, 2011).

For the composition of the bycatch, we only used beetle families. For the difference in beetle bycatch composition, we used the absence and presence of the families. The dissimilarity in beetle families between the pheromones was analysed with PERManova (Anderson, 2001). For the dependent variable, a matrix was made with the families in the columns and traps in the rows. The independent variables were the type of pheromone and type of disturbance. The analysis was done with 999 permutations, and the Jaccard index was used. The results were presented with an NMDS using the Jaccard index. The PERManova was done with the 'vegan' library (Oksanen et al., 2013) in the statistical program R (R Core Team, 2018).

In order to determine which beetle family was attracted to a specific pheromone, an IndVal analysis was done. We only did this analysis for the pheromones and used 999 permutations when computing the model. The 'indicspecies' library in the statistical program $\mathrm{R}$ was used for the analysis (De Caceres \& Legendre, 2009).

To assess the cost-efficiency of the pheromones and their share of the total cost of monitoring, it was necessary to assess all the components that relate to their purchase and use. Here, we present the cost of pheromones, cost of traps and cost of work and travel expenses. All pheromone and trap prices are taken from invoices that we received from companies. District foresters provided the kilometres driven, and for calculating travel expenses, we used the standard price per mile used by the SFS. For calculating the cost of work, the SFS provided us with the average hourly rate for the second gross payment for district foresters, and the hours used for work were also provided by district foresters.

$$
\begin{gathered}
\text { indexTC }=\text { average }\left(\frac{T C}{\operatorname{maxTC}}\right) \\
\text { indexSS }=\frac{\text { average }(T C T x)-\operatorname{average}(T C C x)}{\max (T C T-T C C)} \\
\text { indexBTCTC }=\text { average }\left(\frac{B T C / T C}{\max (B T C / T C)}\right) \\
\text { index }=\frac{\text { indexTC }+ \text { indexSS }+ \text { indexBTCTC }}{3}
\end{gathered}
$$

In the end, we made an index in which we calculated the effectiveness of the pheromones. The index was calculated per pheromone as follows:

1. the average catch index (indexTC), where the total catch of I. typographus beetles per trap (TC) was divided by the maximum catch of beetles for all pheromones of all the traps (maxTC) and then averaged per pheromone;

2. the standardized sensitivity index (indexSS) in which the difference in the average catch of I. typographus beetles per pheromone per trap $(x)$ between disturbed (TCT) and undisturbed areas (TCC) was divided by the maximum difference of the average trap catch of I. typographus beetles per pheromone for all pheromones;

3. the ratio between the bycatch and the catch of I. typographus beetles (indexBTCTC), which is the number of bycatch (BTC) divided by the number of I. typographus beetles (TC), was divided by the maximum ratio of bycatch/catch and averaged per pheromone;

4. All three components were summed and divided by three to obtain the total index of effectiveness (index). The index was then compared with the costs of the pheromone. 


\section{3 | RESULTS}

In the period from March to September 2019, we collected a total of 586,846 specimens, of which 554,882 specimens were I. typographus and the remaining 32,024 specimens comprised the bycatch.

\subsection{The effectiveness of pheromones for l. typographus}

For the number of I. typographus, the model including the pheromones and disturbance type was the most explanatory (Table 2). IT Ecolure Extra ${ }^{\circledR}$ had a median of 13,711 specimens, Ipsowit ${ }^{\circledR}$ a median of 12,749 specimens, Pheroprax ${ }^{\circledR}$ a median of 11,973 specimens, Ipstyp ${ }^{\circledR}$ a median of 5,234 specimens and Typosan ${ }^{\circledR}$ a median 2,920 specimens. For the pheromones, IT Ecolure Extra ${ }^{\circledR}$ and Pheroprax ${ }^{\circledR}$ had a higher number of caught I. typographus compared to Ipsowit ${ }^{\circledR}$ (Figure 1, Table 3), but the difference was not statistically significant. For Ipstyp $®$ and Typosan $₫$, there were statistically significantly fewer I. typographus caught compared to Ipsowit ${ }^{\circledR}$. A statistically significant increase in I. typographus was observed in the disturbed locations, with a total number of 344,184 specimens, compared to the undisturbed locations, with total number of 210,638 specimens. There were on average more specimens found for the Slovenj Gradec FMA (on average 116,816 specimens) than for the Kranj FMA (on average 102,187 specimens), but the difference was not statistically significant. There was no significant interaction found between pheromones and disturbed compared to undisturbed locations.

\subsection{Changes in the trap catch of I. typographus throughout the season}

The trap catch of I. typographus was different between the different FMAs (Figure 2a). In the Slovenj Gradec FMA, there was one peak observed in early summer $\left(\chi^{2}=10,237, p<0.001\right)$. For the Kranj FMA, there were two peaks, a smaller one in early summer and a larger one in late summer $\left(\chi^{2}=24,390, p<0.001\right)$. The average abundance per sampling period per trap for the Slovenj Gradec FMA was higher than that in the Kranj FMA $(z=5.491, p<0.001)$.

In the Slovenj Gradec FMA, all the pheromones showed one peak, which was the general trend in the beginning of the summer; however, Ipsowit ${ }^{\circledR}$ also showed an additional peak in late summer (Figure 2b; Ipsowit $\AA$ : $\chi^{2}=5,439, p<0.001$; Ipstyp ${ }^{\circledR}$ : $\chi^{2}=3,223$, $p<2 \mathrm{e}-16$; IT Ecolure Extra $\AA: \chi^{2}=6,831, p<0.001$, Pheroprax ${ }^{\circledR}$ : $\chi^{2}=5,895, p<0.001$; Typosan $\left.\AA: \chi^{2}=1,263, p<0.001\right)$. There was a difference in the abundance of I. typographus between pheromones, where Ipstyp ${ }^{\circledR}$ and Typosan ${ }^{\circledR}$ had the lowest catch (compared to Ipsowit $\AA$ : Ipstyp $\AA: z=-23.22, p<0.001$, Typosan $\AA: z=-22.04$, $p<0.001$ ), while IT Ecolure Extra ${ }^{\circledR}$, Ipsowit $\AA$ and Pheroprax $\AA$ had a higher catch (compared to Ipsowit $\AA$ : IT Ecolure Extra $\AA$ : $z=-10.15$, $p<0.001$; Pheroprax ${ }^{\circledR}: F=-13.36, p<0.001$ ).

In the Kranj FMA, Ipsowit ${ }^{\circledR}$, Ipstyp ${ }^{\circledR}$ and IT Ecolure Extra ${ }^{\circledR}$ showed one peak in late summer, while Pheroprax ${ }^{\circledR}$ and Typosan ${ }^{\circledR}$ showed an additional peak in the beginning of the summer (Figure 2c; Ipsowit $\AA: \chi^{2}=2,341.0, p<0.001$; Ipstyp $\AA$ : $\chi^{2}=816.4, p<0.001$; IT Ecolure Extra ${ }^{\circledR}: \chi^{2}=2,654.7, p<0.001$, Pheroprax ${ }^{\circledR}: \chi^{2}=2,901.2$, $p<0.001$; Typosan $\left.\AA: \chi^{2}=973.4, p<0.001\right)$. There was a difference in the abundance of $I$. typographus between the pheromones, where Ipstyp ${ }^{\circledR}$ and Typosan $\AA$ had the lowest catch (compared to Ipsowit $\AA$ : Ipstyp $\AA: z=2.503, p<0.05$, Typosan $\AA: z=-0.442$, $p=0.6587$ ), while IT Ecolure Extra ${ }^{\circledR}$, Ipsowit ${ }^{\circledR}$ and Pheroprax ${ }^{\circledR}$ had a higher catch (compared to Ipsowit ${ }^{\circ}$ : IT Ecolure Extra $\AA$ : $z=9.638$, $p<0.001$; Pheroprax ${ }^{\circledR}: z=14.287, p<0.001$ ).

\section{3 | Bycatch}

The bycatch represented only $5.8 \%$ of the total catch. In total, there were 68 to 2,354 specimens caught per trap during the whole monitoring season. The majority of the bycatch was composed of the order Coleoptera (29,741 specimens). Most specimens belonged to other Curculionidae (24,642), Staphylinidae $(1,255)$, Scarabaeidae (726) and Elateridae (703). Other families had less than 250 specimens caught in the whole season. There were also specimens from

\begin{tabular}{|c|c|c|c|c|c|c|}
\hline \multirow[b]{2}{*}{ Models } & \multicolumn{2}{|c|}{$\begin{array}{l}\text { Number of bark } \\
\text { beetles }\end{array}$} & \multicolumn{2}{|c|}{$\begin{array}{l}\text { Number of by } \\
\text { catch }\end{array}$} & \multicolumn{2}{|c|}{$\begin{array}{l}\text { Number of bark } \\
\text { beetle predators }\end{array}$} \\
\hline & $d f$ & AIC & $d f$ & AIC & $d f$ & AIC \\
\hline $\begin{array}{l}\text { Pheromones } x \\
\text { Disturbance + FMA }\end{array}$ & 12 & $1,005.17$ & 12 & 737.71 & - & - \\
\hline $\begin{array}{l}\text { Pheromones + Disturbance } \\
\text { +FMA }\end{array}$ & 8 & $1,000.03$ & 8 & 740.60 & 14 & 107.71 \\
\hline Pheromones + FMA & 7 & $1,009.78$ & 7 & 740.76 & 12 & 104.92 \\
\hline Disturbance + FMA & 4 & $1,025.92$ & 4 & 750.98 & 6 & 148.01 \\
\hline FMA & 3 & $1,029.14$ & 3 & 749.45 & 4 & 147.28 \\
\hline
\end{tabular}

TABLE 2 Model selection table for the models with pheromones and disturbance area

Note: The models are shown for the number of I. typographus, number of bycatch and number of I. typograhus predators.

The best models, which have the lowest AIC, are shown in bold. 
FIGURE 1 The effect of pheromones and disturbance on the number of caught I. typographus. The grey boxplots show disturbed locations, and the white boxplots show undisturbed locations. The data are represented by the median value, 25th and 75th percentile, and outliers

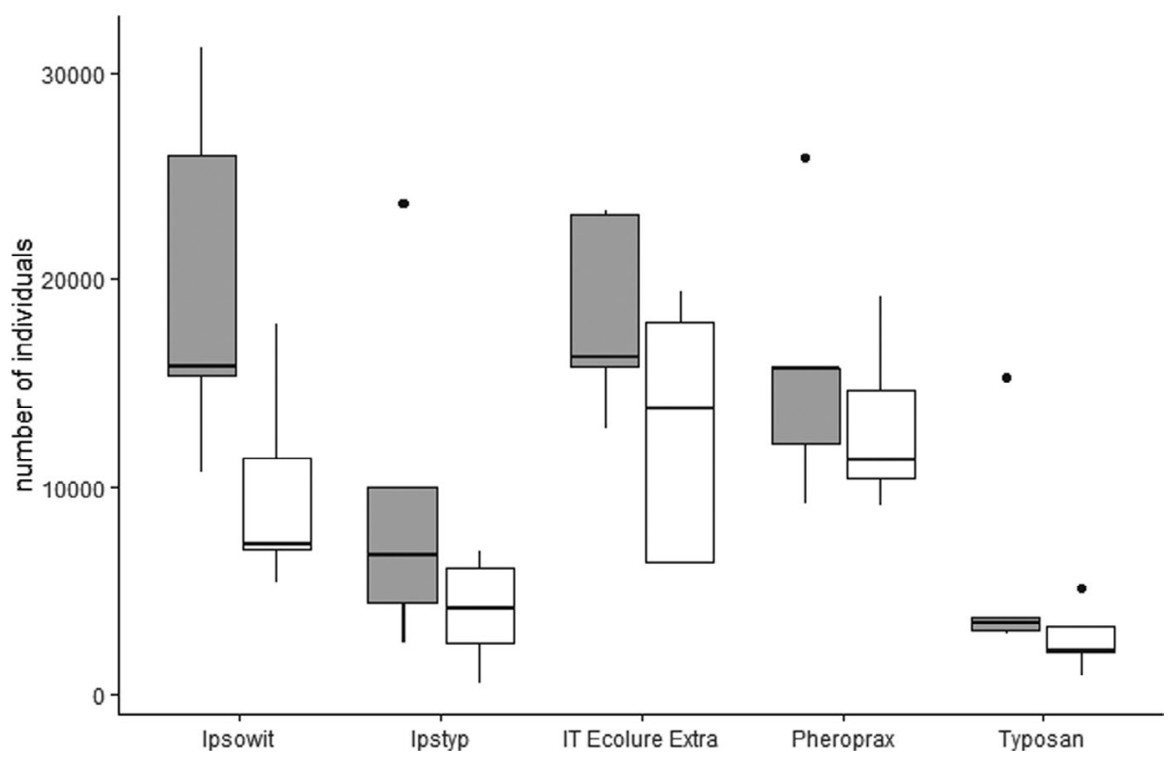

the order Hymenoptera (235 specimens), Hemiptera (196 specimens), Diptera (190 specimens), Dermaptera (115 specimens) and Araneae (92 specimens). All other orders had less than 10 specimens caught in the whole season. IT Ecolure Extra ${ }^{\circledR}$ had a median of 796 specimens, Ipsowit ${ }^{\circledR}$ a median of 654 specimens, Pheroprax ${ }^{\circledR}$ a median of 351 specimens, Ipstyp ${ }^{\circledR}$ a median of 292 specimens and Typosan ${ }^{\circledR}$ a median 135 specimens. The best model for the bycatch included the pheromones, type of disturbance and FMA (Table 2). Compared to Ipsowit ${ }^{\circledR}$, Ipstyp ${ }^{\circledR}$, Typosan $\AA$ and Pheroprax ${ }^{\circledR}$ had a lower bycatch (Figure 3, Table 3), while IT Ecolure Extra ${ }^{\circledR}$ had a higher bycatch. However, the differences were not statistically significant (Table 3). The interaction of the model showed that the differences between the disturbed and undisturbed locations for IT Ecolure Extra ${ }^{\circledR}$, Ipstyp $₫$ and Typosan $₫$ were larger compared to the differences for Ipsowit ${ }^{\circledR}$. However, the differences were not statistically significant. For Pheroprax ${ }^{\circledR}$, the difference was smaller compared to the difference in disturbed and undisturbed locations for Ipsowit ${ }^{\circledR}$, but it also was not statistically significant. Overall, there was a larger amount of bycatch in disturbed locations (median of 452 specimens) compared to undisturbed locations (median of 262 specimens) (Figure 3, Table 3), but the difference was not statistically significant. Nevertheless, we found that there was a statistically significant difference between the number of bycatch specimens between FMAs, with the Slovenj Gradec FMA having higher bycatch abundance than the Kranj FMA (median of 583 vs. 271 specimens, respectively).

There was a difference in the composition of beetle families for the pheromones ( $F=8.5216, R^{2}=0.431, p=0.000999$ ) (Figure 4). An especially large difference was found in family composition between Pheroprax ${ }^{\circledR}$ and IT Ecolure Extra $\AA$ in comparison to Ipstyp ${ }^{\circledR}$ and Typosan ${ }^{\circledR}$ (Figure 4). Ipsowit $®$ was indicative for the Salpingidae family $(N=84)$ (stat $=0.573, p=0.043$ ), and Typosan ${ }^{\circledR}$ was indicative for the families Scydmaenidae $(N=23)$ and Carabidae $(N=115)$ (stat $=0.611, p=0.005$, stat $=0.599, p=0.011$ ). For the other pheromones, no indicative family was found, which means that the families were distributed equally across the other pheromones.

\section{4 | Predators}

In our study, the total number of predators amounted to 46 specimens, of which 40 were from the genus Thanasimus (Thanasimus femoralis 26; Thanasimus formicarius 4; Thanasimus spp. 10) and 6 were Nemosoma elongatum. The pheromone with the highest total number of predators caught was Ipstyp ${ }^{\circledR}(19)$ followed by IT Ecolure Extra ${ }^{\circledR}(16)$, Ipsowit ${ }^{\circledR}(5)$ and Pheroprax ${ }^{\circledR}(5)$, and Typosan ${ }^{\circledR}$ (1). For the bycatch of predators, the model including the pheromones and FMA was the best explanatory model (Table 2). There were a larger number of predators caught by Ipstyp ${ }^{\circledR}$ and IT Ecolure Extra ${ }^{\circledR}$ compared to Ipsowit ${ }^{\circledR}$ (Table 3), which was also statistically significant. There was no difference observed between Ipsowit ${ }^{\circledR}$ and the other pheromones. There were in total more specimens found for the Slovenj Gradec FMA (41) than for the Kranj FMA (5), and the difference was statistically significant (Table 3).

\subsection{Budget}

In the experiment, we used 50 traps with stands (Table 4), which cost $€ 29.83$. In total, the costs of work and travel expenses associated with traps were $€ 10,906.66$ and $€ 1,471.86$, respectively (Table 4). The costs of work were relatively high compared to the cost of pheromones. There were large differences in the prices of different pheromones, with Pheroprax $\AA$ being the most expensive. Travel expenses and the cost of traps represented the smallest shares of total monitoring costs, that is, $9.2 \%$ and $9.4 \%$, respectively. The pheromones were somewhat more expensive and represented $12.8 \%$ of 
TAB LE 3 Model statistics of the effectiveness, bycatch and I. typographus predator model. The other pheromones are compared to Ipsowit $\AA$, undisturbed locations are compared to disturbed locations and the Slovenj Gradec FMA is compared to the Kranj FMA. The hurdle model prepared for the number of predators shows two models: a truncated Poisson model for the abundance above zero and a binomial model for the probability of predators of $I$. typographus

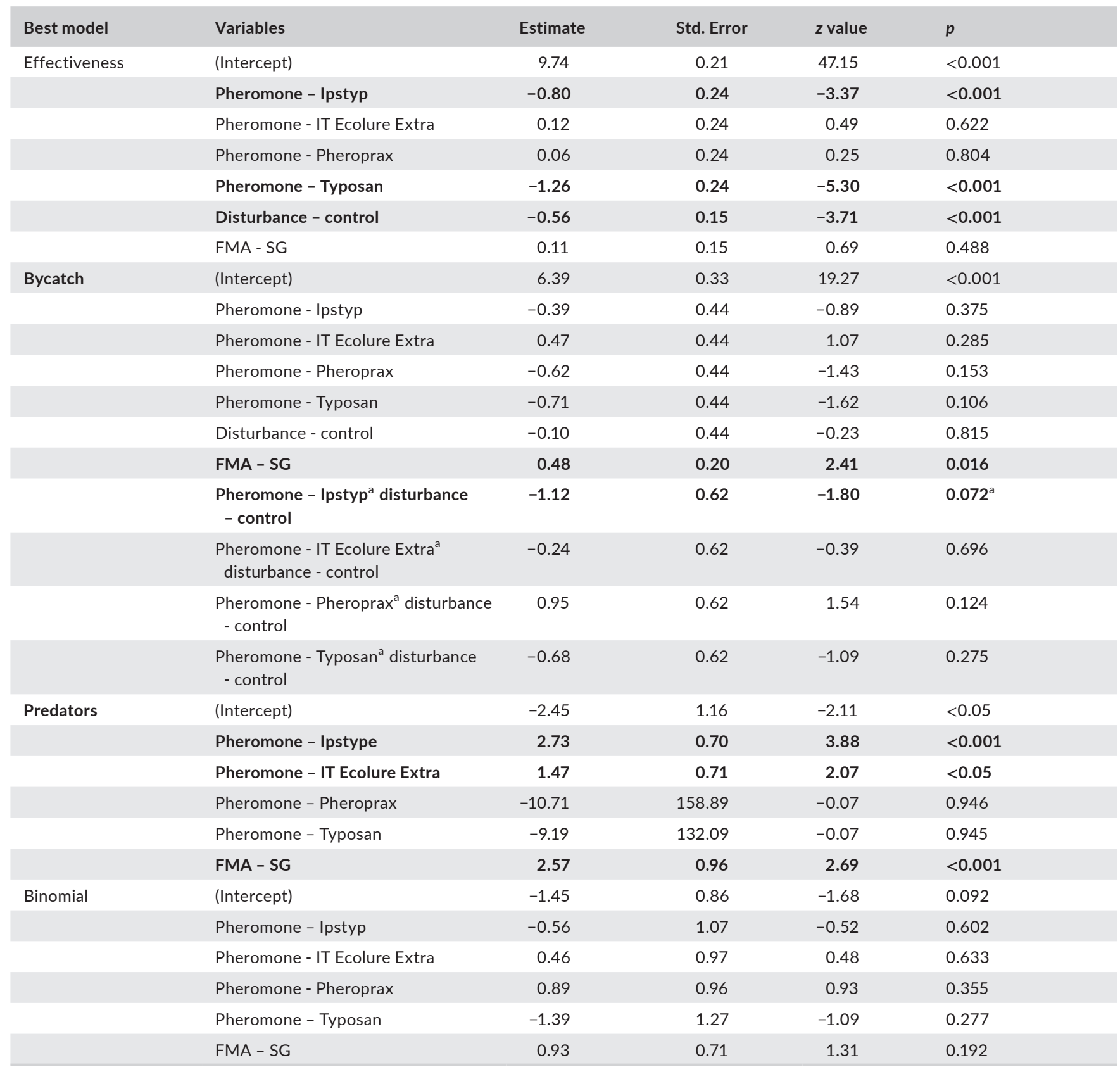

Note: Differences with significant values are shown in bold.

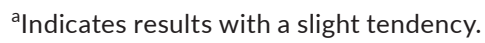

all costs. The costs of work represented the highest percentage of all costs, that is, $68.6 \%$ (Table 4).

\subsection{Cost-efficiency index}

The index showed that the pheromones had different scores for the number of caught I. typographus, sensitivity for disturbed and undisturbed locations and ratio of bycatch/catch (Table 5).
Ipsowit ${ }^{\circledR}$ had the best performance. Relative to pheromone costs, the most expensive pheromone was not as good as the cheapest one.

\section{DISCUSSION}

A trapping system using synthetic pheromone lures has been an established method for monitoring populations of I. typographus 
FIGURE 2 The changes in the trap catch of $I$. typographus for the FMAs (a) and difference in pheromones for the Slovenj Gradec FMA (b) and Kranj FMA (c). The background shows the raw data
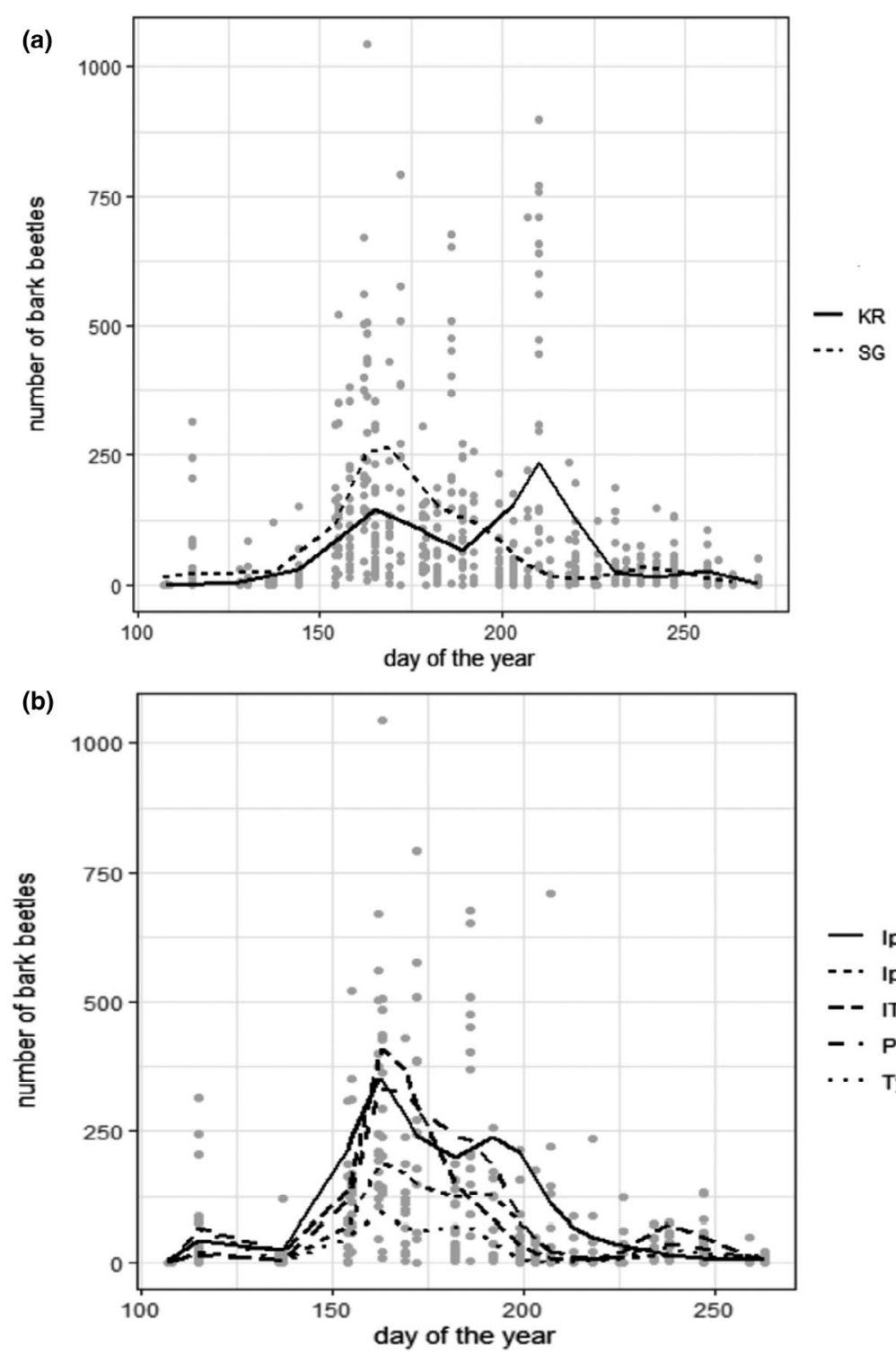

- Ipsowit

- - Ipstyp

- - IT Ecolure Extra

- Pheroprax

... Typosan

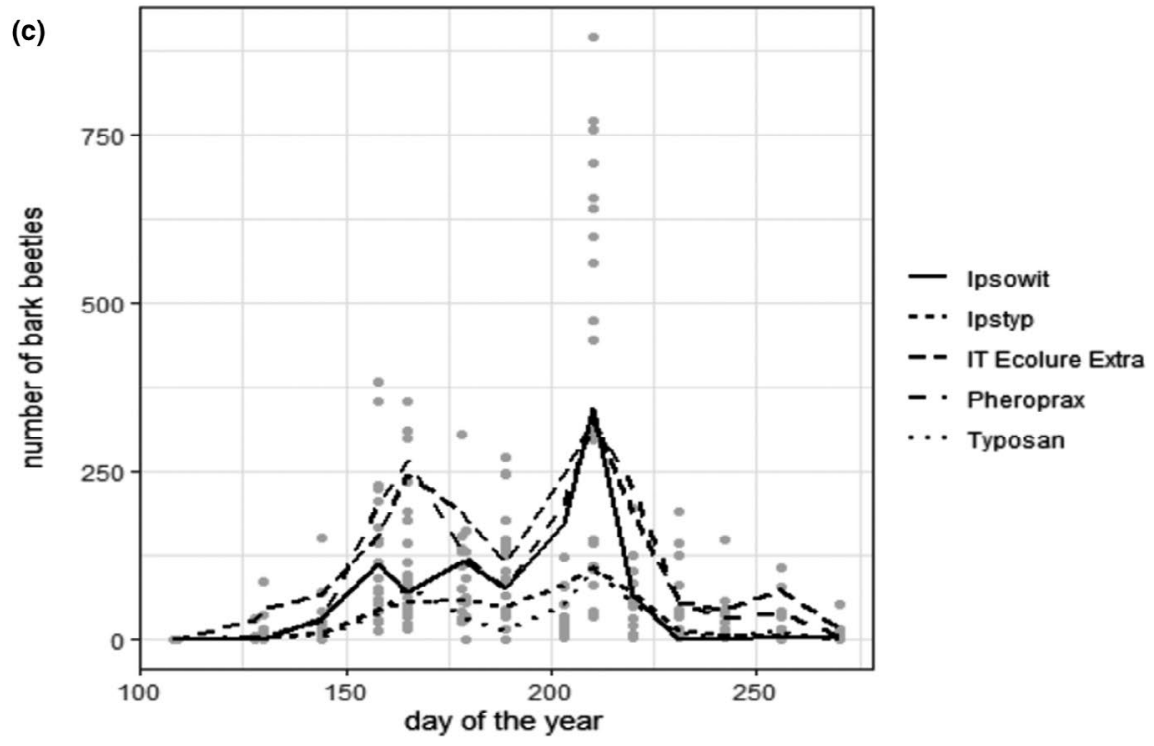

in Slovenia and Europe for decades. Moreover, it has been shown that pheromone traps can be used to assess the risk of damage caused by I. typographus (Duelli et al., 1997; Vité, 1989;
Weslien et al., 1989). Since the discovery of the key aggregation pheromone components of I. typographus in the 1960s (Bakke et al., 1977), several commercial products have been put on the 


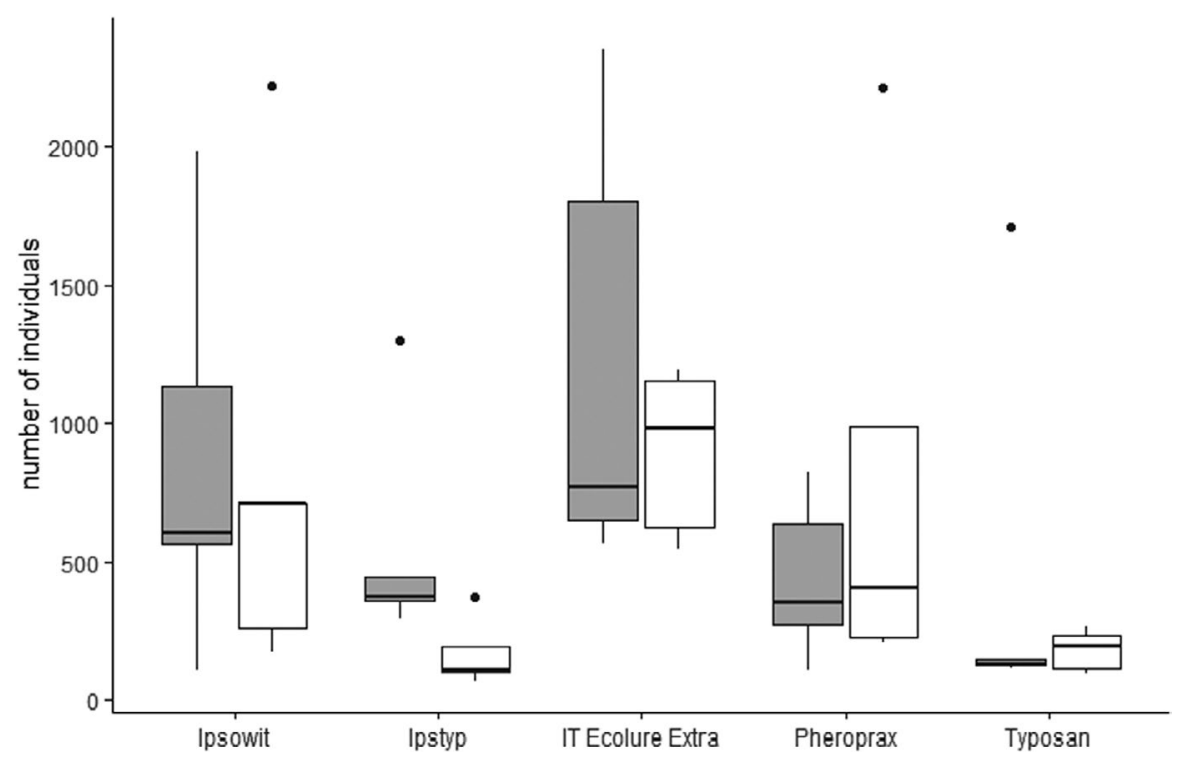

FIGURE 3 Difference in bycatch between the different pheromones. The grey boxplots show disturbed locations, and the white boxplots show undisturbed locations. The data are represented by the median value, confidence interval, and the dots represent outliers

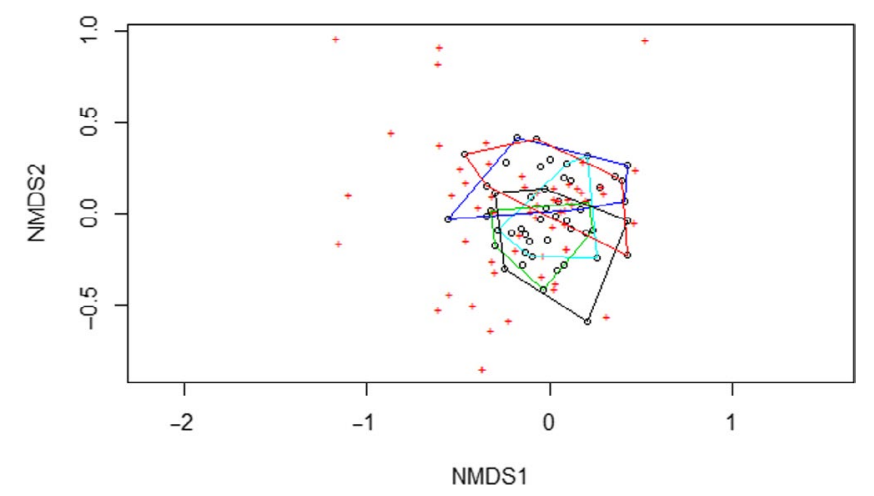

FIGURE 4 NMDS plot of the difference in family composition caught as bycatch between the different pheromones. The light blue line shows Ipsowit ${ }^{\circledR}$, the dark blue line shows Ipstyp ${ }^{\circledR}$, the green line shows IT Ecolure Extra ${ }^{\circledR}$, the black line shows Pheroprax ${ }^{\circledR}$ and the red line shows Typosan ${ }^{\circledR}$

market as synthetic aggregation pheromone lures for I. typographus. For assessing which of them is the most effective and affordable at the same time, we compared the trapping efficiency of five pheromones (IT Ecolure Extra $\AA$, Typosan $\AA$, Ipstyp ${ }^{\circledR}$, Ipsowit ${ }^{\circledR}$, and Pheroprax ${ }^{\circledR}$ ) in two different treatments (disturbed and undisturbed locations).

Pheromones are a mix of volatile chemical components that induce changes in the behaviour of specimens of the same species (Bakke, 1981; Birgersson et al., 1984; Dickens, 1981; Schlyter et al., 1987; Schlyter et al., 1987; Schlyter et al., 1987). Different pheromones are released in different stages of I. typographus aggregation (Birgersson et al., 1984) and therefore have a different influence on behaviour (Bakke, 1981; Dickens, 1981; Birgersson et al., 1984; Dickens, 1981; Schlyter, Löfqvist, et al., 1987; Schlyter, Birgersson, et al., 1987; Schlyter, Byers, et al., 1987). For I. typographus, 2-methyl-3-buten-2-ol and cis-verbenol were found as essential components for attraction (Bakke, 1981; Birgersson et al., 1984;
TABLE 4 The total cost of work force and travel expenses, including the cost of all the traps with stands and pheromone cost

\begin{tabular}{llll} 
& Cost & Total cost & $\begin{array}{l}\text { Percentage } \\
\text { (\%) }\end{array}$ \\
$\begin{array}{l}\text { Logistics } \\
\text { Cost of traps and } \\
\text { stands }\end{array}$ & & $€ 1,491.50$ & 9.4 \\
Cost of the work force & & $€ 10,906.66$ & 68.6 \\
Travel expenses & & $€ 1,471.86$ & 9.2 \\
Pheromones & & & \\
IT Ecolure Extra & $€ 351.22$ & $€ 2029.80$ & 12.8 \\
Ipstyp & $€ 236.98$ & & \\
Ipsowit & $€ 480.42$ & & \\
Typosan & $€ 350.20$ & & \\
Pheroprax & $€ 610.98$ & & \\
\hline Total & & $€ 15,899.82$ & 100 \\
\hline
\end{tabular}

anitial costs of the traps, but they can be used over several seasons.

Schlyter, Löfqvist, et al., 1987; Schlyter, Birgersson, et al., 1987; Schlyter, Byers, et al., 1987; Vité, 1989). Adding verbenone and ipsenol to the mixture of the synthetic aggregation pheromone significantly reduces the catch, which means that verbenone and ipsenol act as inhibitors (Bakke, 1981). Birgersson et al. (1984) noticed that ipsenol and ipsdienol are not present in the initial aggregation and are first produced only by males after the females enter the nuptial chamber, and especially high quantities are released when females start to lay eggs. He proposed that ipsdienol has a different behavioural role and that it might act as a hormonal control of I. typographus production. When low quantities of ipsdienol were added to a mixture of methylbutenol and cis-verbenol, the trap catch increased (Birgersson et al., 1984; Schlyter, Byers, et al., 1987). However, if a higher quantity of ipsdienol was added to the mixture, the catch decreased (Schlyter, Byers, et al., 1987). Furthermore, Dickens (1981) showed in his research that there are different detection thresholds 
TAB LE 5 Standardized index compared to the different pheromones

\begin{tabular}{lllllr} 
Pheromones & $\begin{array}{l}\text { Average catch index } \\
\text { per trap (indexTC) }\end{array}$ & $\begin{array}{l}\text { Standardized } \\
\text { sensitivity (indexSS) }\end{array}$ & $\begin{array}{l}\text { Average index ratio catch/ } \\
\text { bycatch (indexBTCTC) }\end{array}$ & $\begin{array}{l}\text { Combined } \\
\text { index (index) }\end{array}$ & $\begin{array}{l}\text { Pheromone } \\
\text { costs }\end{array}$ \\
\hline Ipsowit & 0.47 & 1.00 & 0.59 & 0.69 & $€ 480.42$ \\
\hline Ipstyp & 0.22 & 0.54 & 0.52 & 0.42 & 0.50 \\
\hline IT Ecolure Extra & 0.50 & 0.55 & 0.46 & 0.49 & $€ 351.22$ \\
\hline Pheroprax & 0.46 & 0.28 & 0.73 & 0.33 & $€ 610.98$ \\
\hline Typosan & 0.13 & 0.30 & 0.55 & $€ 350.20$ \\
\hline
\end{tabular}

of a certain chemical and that the threshold differs between females and males of I. typographus. He also proposed that 2-methyl-3-buten-2-ol could be a short-range orientation pheromone. In addition, a combination of different chemicals yields different results (Bakke, 1981; Birgersson et al., 1984; Dickens, 1981; Schlyter, Löfqvist, et al., 1987; Schlyter, Birgersson, et al., 1987; Schlyter, Byers, et al., 1987). The effectiveness of a pheromone not only depends on its chemical structure, but also on the ratio of chemicals used. As seen from Schlyter, Löfqvist, et al. (1987), a mixture with a larger quantity of 2-methyl-3-buten-2-ol than of (4S)-cis-verbenol has the most significant influence on catch effectiveness. They also noticed that increasing (4S)-cis-verbenol to 10 times higher than the standard amount decreases the male proportion by $14 \%$. When raising 2-methyl-3-buten-2-ol to 20 times higher, the effect on the male proportion decreased only slightly.

Our results show that pheromones can be put into two groups. The first group consists of pheromones with high effectiveness: IT Ecolure Extra $\AA$, Pheroprax $\AA$ and Ipsowit $\AA$. The second group consists of pheromones with low effectiveness: Ipstyp ${ }^{\circledR}$ and Typosan ${ }^{\circledR}$. Because the exact concentrations of the ingredients in the pheromones used were not given, it is difficult to explain why there was such a large difference between the numbers of beetles caught in traps lured by Pheroprax ${ }^{\circledR}$ (with a very high number) and Ipstyp ${ }^{\circledR}$ (with a very low number) even though both lures contained cis-verbenol and 2-methyl-3-buten-2-ol. We can only speculate that the reason could be the difference in chemical ratio or the different amount of content, or perhaps the chemicals are released differently because of different types of packaging, that is, Pheroprax ${ }^{\circledR}$ is available as an ampule and Ipstyp $\AA$ as a blotter. Even based on the ingredients themselves, it is difficult to determine why IT Ecolure Extra ${ }^{\circledR}$, Pheroprax ${ }^{\circledR}$ and Ipsowit ${ }^{\circledR}$ are so similar in effectiveness. The same is true for the similarity in effectiveness between Ipstyp ${ }^{\circledR}$ and Typosan ${ }^{\circledR}$. What is interesting is that our results contrast those of Göktürk et al. (2005), who found Ipsowit ${ }^{\circledR}$ to be less effective than Ipstyp $\AA$ and Typosan $\AA$. However, in that study the traps were set in late May for 45 days, while our results cover the whole season. There are also some differences between our results and those from the neighbouring country of Croatia (Pernek, 2002). The most effective pheromone was also Pheroprax $\AA$; however, Ipsowit ${ }^{\circledR}$ was nearly as effective as Pheroprax ${ }^{\circledR}$, while IT Ecolure Extra ${ }^{\circledR}$ was significantly less effective (Pernek, 2002). Since the compositions of pheromones were not given in the articles mentioned, the answer for the difference in results might lie in changes in the composition of commercially available pheromones since that time. Galko et al. (2010) and Zahradník and Zahradníková (2014) also found Pheroprax ${ }^{\circledR}$ to be the most efficient. Galko et al. (2010) compared it to the Ipslure ${ }^{\circledR}$, which had the same components as Pheroprax ${ }^{\circledR}$, that is, cis-verbenol, ipsdienol and methylbutenol. Nevertheless, the catch with Ipslure ${ }^{\circledR}$ was two times lower than the catch with Pheroprax ${ }^{\circledR}$. Although Ipslure ${ }^{\circledR}$ was not used in our experiment, its efficiency is comparable to the efficiency of Ipstyp ${ }^{\circledR}$ and Typosan ${ }^{\circledR}$. Two of their assumptions as to why there is such a big difference in efficiency were similar to ours: (i) lower/larger content of active substance and differences in the ratio of chemicals used and (ii) Ipslure ${ }^{\circledR}$ might behave differently in different climates. Zahradník and Zahradníková (2014) observed that when comparing the data gathered in the exchange treatment, a higher number of I. typographus were caught in the traps with Pheroprax ${ }^{\circledR}$, followed by traps with IT Ecolure Mega ${ }^{\circledR}$, FeSex Typo ${ }^{\circledR}$, IT Ecolure Extra ${ }^{\circledR}$, Pheagr IT Forte ${ }^{\circledR}$, IT Ecolure Tubus ${ }^{\circledR}$, Pheagr IT Extra ${ }^{\circledR}$, Pheagr IT $®$, PCIT Ecolure ${ }^{\circledR}$ and PCHIT Etokap ${ }^{\circledR}$. These results are in contrast with our results, since in our study, Pheroprax ${ }^{\circledR}$ had a lower number of caught I. typographus than IT Ecolure Extra ${ }^{\circledR}$. According to the provided contents of the pheromones from Zahradník and Zahradníková (2016), the ingredients are the same as those used in our study. However, the stated length of efficacy did change from the time their experiment was carried out, which might mean that the ratio of chemicals might have also changed.

Nevertheless, the most expensive pheromone Pheroprax ${ }^{\circledR}$ did not have the highest efficiency for catching I. typographus. Even Ipsowit $\AA$, which was the second most expensive pheromone, did not have the highest efficiency. IT Ecolure Extra ${ }^{\circledR}$, which is half the price of Pheroprax ${ }^{\circledR}$, had the highest efficiency. We are thus able to confirm our first hypothesis that the most expensive pheromone might not also be the most efficient one. From this, we can conclude that pheromone producers are improving their products and that evaluation of their efficiency and efficacy is necessary. In addition, as seen from Galko et al. (2010) and other research (Bakke, 1989; Galko et al., 2016; Martín et al., 2013), the type of trap is another variable that should be taken into the account when setting up monitoring or an experiment. The results for the comparison between the two chosen locations show that on average, more I. typographus were caught in the Slovenj Gradec FMA than in the Kranj FMA, but the difference was not statistically significant when looking only at the whole catch. When analysing the abundance separately through time, the difference between the FMAs became more apparent and statistically significant. 
We also found significant differences in the trap catches between the chosen FMAs. The Slovenj Gradec FMA had one significant peak for all pheromones at the beginning of the summer, and only one pheromone (Ipsowit $\left.{ }^{\circledR}\right)$ showed one additional peak in late summer. In contrast, for the Kranj FMA, we found one peak for all pheromones in late summer and one additional peak for two pheromones (Pheroprax ${ }^{\circledR}$ and Typosan ${ }^{\circledR}$ ) at the beginning of the summer. The explanation for the difference in trap catches might lie in the overall difference in altitudes between the chosen FMAs. The traps in the Slovenj Gradec FMA were set at an average altitude of $885 \mathrm{~m}$ for Mislinja and $898 \mathrm{~m}$ for Slovenj Gradec, while those in the Kranj FMA were set at an average altitude of $957 \mathrm{~m}$ for Jezersko and $989 \mathrm{~m}$ for Tržič, meaning that traps in the Kranj FMA were exposed to a higher overall altitude than those in the Slovenj Gradec FMA and consequently to lower yearly temperatures. From the biology of I. typographus, we know that the development time (Ogris et al., 2019; Wermelinger \& Seifert, 1998) and consequently flight season strongly correlate with temperature (Faccoli, 2009).

Our prediction that a difference in the numbers of caught $I$. typographus can be observed between disturbed and undisturbed locations was confirmed. Traps with the same synthetic aggregation pheromone caught more I. typographus in disturbed locations compared to traps set in undisturbed locations. The results are consistent with the findings of Angst et al. (2012) that the abundance of I. typographus decreases from infested sites towards non-infested sites. According to this study, the abundance of I. typographus is also affected by the composition of the habitat, with abundance in forests being two times higher than that in open areas (Angst et al., 2012). When comparing the efficiency and sensitivity results to distinguish the undisturbed location from the disturbed location, the pheromone IT Ecolure Extra ${ }^{\circledR}$, which had the highest efficiency, was not the one with the highest sensitivity. The pheromone with better sensitivity than IT Ecolure Extra ${ }^{\circledR}$ was Ipsowit ${ }^{\circledR}$. Therefore, we reject our second hypothesis that the pheromone with the highest catch rate would also be the one that shows the highest difference between disturbed and undisturbed locations.

It is known that synthetic aggregation pheromones used in monitoring I. typographus may also attract non-target insects (Panzavolta et al., 2014; Valkman et al., 1997; Wermelinger, 2002) or 'bycatch'. When deciding which pheromone to use, it is favourable to use one that attracts the lowest number of bycatch species. Our results show that the total number of specimens considered as bycatch was much smaller than the number of $I$. typographus caught in traps, regardless of the pheromone used. This coincides with the results of Valkman et al. (1997), even though they used the 1979 black drainpipe trap model and only the Ipslure ${ }^{\circledR}$ pheromone. However, our results contrast those of Panzavolta et al. (2014), which could be due to different pheromones and traps used by Panzavolta, that is, pheromones for Ips sexdentatus and Lindgren multiple funnel traps (Lindgren, 1983).

The pattern of bycatch was similar to the pattern of I. typographus catch for all five pheromones; therefore, we confirm the first part of the third hypothesis. The bycatch was composed mostly of
Coleoptera. The Coleoptera families caught are mostly the same as those found in other studies, with other Curculionidae taxa being the most abundant, followed by Staphylinidae, Scarabaeidae and Elateridae species (Panzavolta et al., 2014; Valkman et al., 1997; Wermelinger, 2002). Between 90 and 250 specimens across whole season were also caught from the orders of Hymenoptera, Hemiptera, Diptera, Dermaptera and Araneae. The model showed that, overall, there was no difference between disturbed and undisturbed locations; only the pheromone Ipstyp ${ }^{\circledR}$ had a slightly higher difference between disturbed and undisturbed locations, with disturbed locations having higher abundance. According to Müller et al. (2008), the gaps made by I. typographus positively correlate with the diversity of true bugs, bees and wasps and have the most significant impact on saproxylic beetles. However, further research is needed. There was also a noticeable difference in representation of different beetle families caught as bycatch between the pheromones used. In pheromone traps with Ipsowit $\AA$, the most indicative beetle family was Salpingidae. Some researchers have identified certain species from the family Salpingidae as predators of I. typographus (Panzavolta et al., 2014; Wermelinger, 2002) and suggest that synthetic pheromones can act as kairomones for them. For traps with the pheromone Typosan ${ }^{\circledR}$, the family Scydmaenidae and Carabidae were the most indicative. For other pheromones, Coleoptera families were equally represented. Pheromone mixtures may also contain terpenes and other host-specific chemicals that attract species that use weakened or decomposing trees as breeding or foreign habitat (Panzavolta et al., 2014; Valkman et al., 1997). Therefore, although some pheromones overlap, we can still confirm our third hypothesis that pheromones had different bycatch composition. Overall, there was a higher number of bycatch beetles in the Slovenj Gradec FMA than in the Kranj FMA. This could be explained by the higher altitude of the traps in the Kranj FMA compared to the those in the Slovenj Gradec FMA, as seen in the catch of I. typographus beetles.

The predatory Clerid beetles (Thanasimus spp.) are among the most effective natural enemies of I. typographus (Martín et al., 2013; Weslien, 1994). Wermelinger (2004) also confirmed a positive correlation between the number of Thanasimus formicarius specimens and the number of $I$. typographus specimens. Bakke and Kvamme (1981) found that the pheromones ipsenol and ipsdienol, which are naturally produced by I. typographus, act as kairomones or attractants for Thanasimus species. They also found that adding cis-verbenol to the mixture enhances attractiveness. The synergistic effect was also found when mixing methylbutenol with cis-verbenol and Ipsdienol, even though it had no effect when applied alone. In our study, the total number of predators amounted to 46 specimens, of which 40 were from the genus Thanasimus and six specimens were Nemosoma elongatum. In all cases, the number of predators did not exceed five specimens per collection of the trap sample. This is in agreement with the fact that $T$. formicarius readily escapes from the container of slit traps. In addition, other studies have shown that slit traps are of little concern regarding the bycatch of Thanasimus formicarius beetles (Martín et al., 2013), which might be the case in our study, and could apply to our catch 
of Thanasimus formicarius, as well as for Nemosoma elongatum and Thanasimus femoralis. The pheromones with the highest total number of predators caught were Ipstyp ${ }^{\circledR}$ and IT Ecolure Extra ${ }^{\circledR}$. Other pheromones had much lower numbers of specimens. The reason could be related to the different concentrations of ipsdienol, methylbutenol and cis-verbenol in the pheromone mixture. Zhang and Schlyter (2010) found that adding two C8-alcohols (3-octanoland 1-octen-3-ol) to the kairomone mixture (aggregation pheromones for I. typographus) decreases the catch of $T$. formicarius by more than $36 \%$. Unfortunately, the two C8-alcholos also decreased the catch of I. typographus. However, none of the pheromone producers stated that these alcohols are present in their pheromone mixture and none of the listed components of the pheromones acted as an inhibitor for T. formicarius. From the gathered data, we can conclude that the pattern of predator catch was not similar to the pattern of I. typographus catch for all five pheromones; therefore, we reject the second part of the third hypothesis.

As we found for I. typographus and the bycatch, there were more specimens caught in the Slovenj Gradec FMA than in the Kranj FMA, which can also be explained by altitude and the lifestyle of Thanasimus species, which are density dependent on I. typographus (Weslien, 1994).

From the budget analysis, where we compared five different commercially available pheromones, we can see that in our case, the pheromones represented $12.8 \%$ of the total cost of monitoring. If only the cheapest pheromones were used, their percentage would drop to $7.5 \%$ of the total cost, and if only the most expensive ones were used, the percentage would rise to $19.2 \%$ of the total cost. Even though the pheromone and trap costs in our research were relatively low, we can see from the control programme report of Bakke (1989) that the cost of pheromones and traps can represent up to one third of the total cost. Nevertheless, pheromone cost did not represent a significant share of the total cost of our monitoring, and therefore, we reject our last hypothesis.

\section{CONCLUSIONS}

In conclusion, we found that different pheromones yield different results under opposing disturbance circumstances. A pheromone should be effective and catch many beetles, but also show outbreaks and differences in the trap catch of I. typographus. In this way, foresters can anticipate future outbreaks (Faccoli \& Stergulc, 2006) and respond as soon as possible. We show that pheromones which attract a large number of beetles do not necessarily distinguish between disturbed and undisturbed areas. Another important aspect when deciding on which pheromone to use is the bycatch. The more effective pheromones do not necessarily have the highest bycatch. In comparison with the economic evaluation, the most expensive pheromone was not necessarily the one which was most efficient and had the lowest bycatch. However, the costs of the pheromones are only minor compared to the total monitoring budget including logistics. Taking these factors into account when deciding on the appropriate pheromones would give the best option for quickly reacting to potential outbreaks, but also have as less potential impact on non-target organisms. This framework allows us to make a constructive decision regarding the best pheromone for monitoring I. typographus, which is important for responding to outbreaks in forests in a changing world.

\section{ACKNOWLEDGEMENTS}

We would like to thank the foresters from ZGS that helped with the sampling of the traps and Eva Groznik for helping to sort the samples. The authors acknowledge the project 'Improvement of the monitoring system for catching spruce bark beetles in control pheromone traps and the system of setting of control traps, and the development of an application for location planning and abundance of control traps and trap logs by regulatory units of the Slovenia Forest Service' (V4-1822), which was financially supported by the Slovenian Research Agency and the Ministry of Agriculture, Forestry and Food.

\section{CONFLICT OF INTEREST}

There was no conflict of interest.

\section{AUTHOR CONTRIBUTIONS}

MG and AK conceived the ideas and designed methodology; AK and MK coordinated the fieldwork; NS performed the species identification and prepared the data for analysis; MG analysed the data; NS led the writing of the manuscript. All authors contributed critically to the drafts and gave final approval for publication.

\section{DATA AVAILABILITY STATEMENT}

All data underlying the analyses and the $R$ scripts in this study are available on Dryad (https://datadryad.org/stash/share/V7vof WmxsOibiWI-prb9OwpZojUu08QiHOmHAuxiAp8, de Groot et al., 2020).

\section{ORCID}

Nina Šramel (iD https://orcid.org/0000-0003-3451-6497

Andreja Kavčič iD https://orcid.org/0000-0002-0302-955X

Maarten de Groot (iD https://orcid.org/0000-0002-5721-6676

\section{REFERENCES}

Anderson, M. J. (2001). A new method for non-parametric multivariate analysis of variance. Austral Ecology, 26, 32-46. https://doi.org/10.11 11/j.1442-9993.2001.01070.pp.x

Angst, A., Rüegg, R., \& Forster, B. (2012). Declining bark beetle densities (Ips typographus, Coleoptera: Scolytinae) from infested Norway spruce stands and possible implications for management. Psyche A Journal of Entomology, 3, 1-7. https://doi.org/10.1155/2012/321084

Baier, P., Pennerstorfer, J., \& Schopf, A. (2007). PHENIPS-a comprehensive phenology model of Ips typographus (L.) (Col., Scolytinae) as a tool for hazard rating of bark beetle infestation. Forest Ecology and Management, 249, 171-186. https://doi.org/10.1016/j. foreco.2007.05.020 
Bakke, A. (1981). Inhibition of the response in Ips typographus to the aggregation pheromone; field evaluation of verbenone and ipsenol. Zeitschrift Für Angewandte Entomologie, 92, 172-177. https://doi. org/10.1111/j.1439-0418.1981.tb01666.x

Bakke, A. (1989). The recent Ips typographus outbreak in Norway Experiences from a control program. Holarctic Ecology, 12, 515-519. https://doi.org/10.1111/j.1600-0587.1989.tb00930.x

Bakke, A., Frøyen, P., \& Skattebøl, L. (1977). Field response to a new pheromonal compound isolated from Ips typographus. Naturwissenschaften, 64, 98-99. https://doi.org/10.1007/BF00437364

Bakke, A., \& Kvamme, T. (1981). Kariomone response in Thanasimus predators to pheromone components of Ips typographus. Journal of Chemical Ecology, 7(2), 305-312. https://doi.org/10.1007/BF00995753

Birgersson, G, Schlyter, F, Löfqvist, J, \& Bergström, G (1984). Quantitative variation of pheromone components in the spruce bark beetle Ipstypographus from different attack phases. Journal of Chemical Ecology, 10, 1029-1055.

Bončina, A., Klopčič, M., Simončič, T., Dakskobler, I., Ficko, A., \& Rozman, A. (2017). A general framework to describe the alteration of natural tree species composition as an indicator of forest naturalness. Ecological Indicators, 77, 194-204. https://doi.org/10.1016/j.ecoli nd.2017.01.039

Buma, B. (2015). Disturbance interactions: Characterization, prediction, and the potential for cascading effects. Ecosphere, 6(4), 1-15. https:// doi.org/10.1890/ES15-00058.1

Burnham, K. P., \& Anderson, D. R. (2004). Model Selection and Multimodel Inference: A Practical Information-Theoretic Approach. Springer-Verlag.

De Caceres, M., \& Legendre, P. (2009). Associations between species and groups of sites: Indices and statistical inference. Ecology, 90, 35663574. https://doi.org/10.1890/08-1823.1

de Groot, M., Diaci, J., \& Ogris, N. (2019). Forest management history is an important factor in bark beetle outbreaks lesson for the future. Forest Ecology and Management, 433, 467-474. https://doi. org/10.1016/j.foreco.2018.11.025

de Groot, M., \& Ogris, N. (2019). Short-term forecasting of bark beetle outbreaks on two economically important conifer tree species. Forest Ecology and Management, 450, 117495. https://doi.org/10.1016/j. foreco.2019.117495

de Groot, M., Ogris, N., \& Kobler, A. (2018). The effects of a large-scale ice storm event on the drivers of bark beetle outbreaks and associated management practices. Forest Ecology and Management, 408, 195-201. https://doi.org/10.1016/j.foreco.2017.10.035

de Groot, M., Šramel, N., Kavčič, A., \& Kolšek, M. (2020). Difference in effect of pheromone for monitoring the European spruce bark beetle, Dryad, Dataset. Retrieved from https://doi.org/10.5061/dryad. zs7h44j6t

Dickens, J. C. (1981). Behavioural and electrophysiological responses of the bark beetle, Ips typographus, to potential pheromone components. Physiological Entomology, 6, 251-261. https://doi. org/10.1111/j.1365-3032.1981.tb00269.x

Duelli, P., Zahradnik, P., Knizek, M., \& Kalinova, B. (1997). Migration in spruce bark beetles (Ips typographus L.) and the efficiency of pheromone traps. Journal of Applied Entomology, 121, 297-303. https://doi. org/10.1111/j.1439-0418.1997.tb01409.x

Faccoli, M. (2009). Effect of weather on Ips typographus (Coleoptera Curculionidae) phenology, voltinism, and associated spruce mortality in the southeastern Alps. Environmental Entomology, 38, 307-316. https://doi.org/10.1603/022.038.0202. PMID: 19389278

Faccoli, M., \& Stergulc, F. (2006). A practical method for predicting the short-time trend ofbivoltine populations oflps typographus(L.) (Col., Scolytidae). Journal of Applied Entomology, 130, 61-66. https://doi. org/10.1111/j.1439-0418.2005.01019.x

Fettig, C. J., \& Hilszczański, J. (2015). Chapter 14 - Management Strategies for Bark Beetles in Conifer Forests. In F. E. Vega, \& R. W. Hofstetter (Eds)., Bark Beetles - Biology and Ecology of Native and Invasive Species (pp. 555-584). : Elsevier/AP. https://doi.org/10.1016/B978-0-12417156-5.00014-9

Galko, J., Gubka, A., Vakula, J., \& Brutovský, D. (2010). Comparison of catches of the spruce bark beetle (Ips typographus L.) (Coleoptera: Scolytidae) in pheromone traps of Canadian and European production. Lesnícky Časopis - Forestry Journal, 56(4), 337-347. https://doi. org/10.2478/v110114-009-0017-0

Galko, J., Nikolov, C., Kunca, A., Vakula, J., Gubka, A., Zúbrik, M., ... Konôpka, B. (2016). Effectiveness of pheromone traps for the European spruce bark beetle: A comparative study of four commercial products and two new models. Lesnícky Časopis - Forestry Journal, 62, 207-215. https://doi.org/10.1515/forj-2016-0027

Göktürk, T., Akkuzu, E., \& Aksu, Y. (2005). Comparing the effectiveness ratios of pheromone lures of IPSOWIT ${ }$, IPSTYP $\AA$, and TYPOSAN $®$ against Ips typographus (L.) (Col.: Scolytidae). Artvin Çoruh Üniversitesi Orman Fakültesi Dergisi, 6, 155-160. https://doaj.org/article/Ob4f6 7e9408a43bb895e30428b565184

Hallmann, C. A., Sorg, M., Jongejans, E., Siepel, H., Hofland, N., Schwan, H., ... de Kroon, H. (2017). More than 75 percent decline over 27 years in total flying insect biomass in protected areas. PLoS One, 12(10), e0185809. https://doi.org/10.1371/journal.pone.0185809

Kozjek, K., Dolinar, M., \& Skok, G. (2017). Objective climate classification of Slovenia. International Journal of Climatology, 37, 848-860. https:// doi.org/10.1002/joc.5042

Levanič, T., Gričar, J., Gagen, M., Jalkanen, R., Loader, N. N., McCarroll, D., Oven, P., \& Robertson, I. (2009). The climate sensitivity of Norway spruce [Picea abies(L.) Karst.] in the southeastern European Alps. Trees, 23, 169-180. https://doi.org/10.1007/s00468-008-0265-0

Lewis, W. J., van Lenteren, J. C., Phatak, S. C., \& Tumlinson, J. H. (1997). A total system approach to sustainable pest management. Proceedings of the National Academy of Sciences, 94(23), 12243-12248. https:// doi.org/10.1073/pnas.94.23.12243

Lindgren, B. S. (1983). A multiple funnel trap for scolytid beetles (Coleoptera). Canadian Entomologist, 115, 259-273. https://doi. org/10.4039/Ent115299-3

Lindner, M., Maroschek, M., Netherer, S., Kremer, A., Barbati, A., GarciaGonzalo, J., ... Marchetti, M. (2010). Climate change impacts, adaptive capacity, and vulnerability of European forest ecosystems. Forest Ecology and Management, 259(4), 698-709. https://doi.org/10.1016/j. foreco.2009.09.023

Lobinger, G. (1995). Einsatzmöglichkeiten von Borkenkäferfallen. Allg. Forst. Z. Waldwirtsch. Umweltvorsorge, 50, 198-201. https://www. researchgate.net/publication/306193775_Einsatzmoglichkeiten_ von_Borkenkaferfalle

Martín, A., Etxebeste, I., Pérez, G., Álvarez, G., Sánchez, E., \& Pajares, J. (2013). Modified pheromone traps help reduce bycatch of bark-beetle natural enemies. Agricultural and Forest Entomology, 15, 86-97. https://doi.org/10.1111/j.1461-9563.2012.00594.x

Müller, J., Bußler, H., Goßner, M., Rettelbach, T., \& Duelli, P. (2008). The European spruce bark beetle Ips typographus in a national park: From pest to keystone species. Biodiversity and Conservation, 17, 29793001. https://doi.org/10.1007/s10531-008-9409-1

Nagel, T. A., Mikac, S., Dolinar, M., Klopcic, M., Keren, S., Svoboda, M., ... Paulic, V. (2017). The natural disturbance regime in forests of the Dinaric Mountains: A synthesis of evidence. Forest Ecology and Management, 388, 29-42. https://doi.org/10.1016/j. foreco.2016.07.047

Netherer, S., Panassiti, B., Pennerstorfer, J., \& Matthews, B. (2019). Acute Drought is an important driver of bark beetle infestation in Austrian Norway spruce stands. Frontiers in Forests and Global Change, 2, 39. https://doi.org/10.3389/ffgc.2019.00039

Ogris, N., Ferlan, M., Hauptman, T., Pavlin, R., Kavčič, A., Jurc, M., \& de Groot, M. (2019). RITY - A phenology model of Ips typographus as a tool for optimization of its monitoring. Ecological Modelling, 410, 1-14. https://doi.org/10.1016/j.ecolmodel.2019.108775 
Ogris, N., \& Jurc, M. (2010). Sanitary felling of Norway spruce due to spruce bark beetles in Slovenia: A model and projections for various climate change scenarios. Ecological Modelling, 221, 290-302. https://doi.org/10.1016/j.ecolmodel.2009.05.015

Oksanen, J., Blanchet, F. G., Friendly, M., Kindt, R., Legendre, P., McGlinn, D., ... Wagner, H. (2013). Vegan: Community Ecology Package, R package version 2.0-7 edn. Journal of Statistical Software, 48, 1-21. https://www.researchgate.net/publication/282247686_Vegan_ Community_Ecology_Package_R_package_version_20-2

Panzavolta, T., Bracalini, M., Bonuomo, L., Croci, F., \& Tiberi, R. (2014). Field response of non-target beetles to Ips sexdentatus aggregation pheromone and pine volatiles. Journal of Applied Entomology, 138, 586-599. https://doi.org/10.1111/jen.12121

Pernek, M. (2002). Analysis of biological efficiency of pheromone preparations and types of traps used for capturing bark beetle (Ips typographus L. and Pityogenes chalcographus L. (Coleoptera; Scolytidae)). Rad. Šumar. Inst., 37(1), 61-83. https://www.sumins.hr/wp-content/uploa ds/2016/09/04_pernak.pdf

Potterf, M., Nikolov, C., Kočická, E., Ferenčík, J., Mezei, P., \& Jakuš, R. (2019). Landscape-level spread of beetle infestations from windthrown- and beetle-killed trees in the non-intervention zone of the Tatra National Park, Slovakia (Central Europe). Forest Ecology and Management, 432, 489-500. https://doi.org/10.1016/j.foreco.2018.09.050

R Core Team. (2018). R: A Language and Environment for Statistical Computing. R Foundation for Statistical Computing. https://www.r-project.org/

Raffa, K. F., Aukema, B. H., Bentz, B. J., Carroll, A. L., Hicke, J. A., Turner, M. G., \& Romme, W. H. (2008). Cross-scale drivers of natural disturbances prone to anthropogenic amplification: The dynamics of bark beetle eruptions. BioScience, 58(6), 501-517. https://doi. org/10.1641/B580607

Ryall, K. L., \& Fahrig, L. (2005). Habitat loss decreases predator-prey ratios in a pine-bark beetle system. Oikos, 110(2), 265-270. https://doi. org/10.1111/j.0030-1299.2005.13691.x

Sánchez-Bayo, F., \& Wyckhuys, K. A. G. (2019). Worldwide decline of the entomofauna: A review of its drivers. Biological Conservation, 232, 8-27. https://doi.org/10.1016/j.biocon.2019.01.020

Schlyter, F., Birgersson, G., Byers, J. A., Löfqvist, J., \& Bergström, G. (1987). Field response of spruce bark beetle, Ips typographus, to aggregation pheromone candidates. Journal of Chemical Ecology, 13, 701-716. https://doi.org/10.1007/BF01020153

Schlyter, F., Byers, J. A., \& Lofqvist, J. (1987). Attraction to pheromone sources of different quantity, quality, and spacing: Density-Regulation Mechanisms in Bark Beetle Ips typographusl. Journal of Chemical Ecology, 13(6), 1503-1523. https://doi.org/10.1007/BF01012294

Schlyter, F., Löfqvist, J., \& Byers, J. A. (1987). Behavioural sequence in the attraction of the bark beetle Ips typographus to pheromone sources. Physiological Entomology, 12, 185-196. https://doi. org/10.1111/j.1365-3032.1987.tb00741.x.

Seibold, S., Gossner, M. M., Simons, N. K., Blüthgen, N., Müller, J., Ambarlı, D., ... Weisser, W. W. (2019). Arthropod decline in grasslands and forests is associated with landscape-level drivers. Nature, 574(7780), 671-767. https://doi.org/10.1038/s41586-019-1684-3

Seidl, R., Thom, D., Kautz, M., Martin-Benito, D., Peltoniemi, M., Vacchiano, G., ... Reyer, C. P. O. (2017). Forest disturbances under climate change. Nature Climate Change, 7(6), 395-402. https://doi. org/10.1038/nclimate3303

Sturrock, R. N., Frankel, S. J., Brown, A. V., Hennon, P. E., Kliejunas, J. T., Lewis, K. J., Worrall, J. J., \& Woods, A. J. (2011). Climate change and forest diseases. Plant Pathology, 60(1), 133-149. https://doi. org/10.1111/j.1365-3059.2010.02406.x

Valkman, H., Räty, M., \& Niemelä, P. (1997). Catches of Ips duplicatus and other non-target Coleoptera by Ips typographus pheromone trapping. Entomological Fennica, 8, 153-159. https://doi.org/10.33338/ef.83934
Vité, J. P. (1989). The European struggle to control Ips typographus - past, present and future. Holarctic Ecology, 12(4), 520-525. https://doi. org/10.1111/j.1600-0587.1989.tb00931.x

Wermelinger, B. (2002). Development and distribution of predators and parasitoids during two consecutive years of an Ips typographus (Col., Scolytidae) infestation. Journal of Applied Entomology, 126, 521-527. https://doi.org/10.1046/j.1439-0418.2002.00707.x

Wermelinger, B. (2004). Ecology and management of the spruce bark beetle Ips typographus - A review of recent research. Forest Ecology and Management, 202(1-3), 67-82. https://doi.org/10.1016/j. foreco.2004.07.018

Wermelinger, B., \& Seifert, M. (1998). Analysis of the temperature dependent development of the spruce bark beetle Ips typographus (L.) (Col., Scolytidae). Journal of Applied Entomology, 122, 185-191. https://doi.org/10.1111/j.1439-0418.1998.tb01482.x

Weslien, J. (1994). Interactions within and between species at different densities of the bark beetle Ips typographus and its predator Thanasimus formicarius. Entomologia Experimentalis et Applicata, 71, 133-143. https://doi.org/10.1111/j.1570-7458.1994.tb01779.x

Weslien, J., Annila, E., Bakke, A., Bejer, B., Eidmann, H. H., Narvestad, K., Nikula, A., \& Ravn, H. P. (1989). Estimating risks for spruce bark beetle (Ips typographus (L.)) damage using pheromone-baited traps and trees. Scandinavian Journal of Forest Research, 4(1-4), 87-98. https:// doi.org/10.1080/02827588909382549

Wichmann, L., \& Ravn, H. P. (2001). The spread of Ips typographus (L.) (Coleoptera, Scolytidae) attacks following heavy windthrow in Denmark, analyzed using GIS. Forest Ecology and Management, 148, 31-39. https://doi.org/10.1016/S0378-1127(00)00477-1

Wood, S. N. (2011). Fast stable restricted maximum likelihood and marginal likelihood estimation of semiparametric generalized linear models. Journal of the Royal Statistical Society (B), 73(1), 3-36. https://doi. org/10.1111/j.1467-9868.2010.00749.x

Zahradník, P., \& Zahradníková, M. (2014). Evaluation of the efficacy duration of different types of pheromone dispensers to lure Ips typographus (L.) (Coleoptera: Curculionidae: Scolytinae). Journal of Forest Science, 60, 456-463. https://doi.org/10.17221/15/2014-JFS

Zahradníková, M., \& Zahradník, P. (2016). Metodická příručka INTEGROVANÉ OCHRANY ROSTLIN PRO LESNÍ POROSTY - Př́loha 1. Seznam povolených prípravků a dalších prostředků na ochranu lesa 2016-). . : Lesnická práce, s.r.o. https://www.vulhm.cz/files/uploa ds/2019/06/Seznam-PCHP-2019_5-FINAL-Iq.pdf.

ZGS. (2012a). Gozdnogospodarski Načrt Gozdnogospodarskega Območja Kranj (2011-2020).

ZGS. (2012b). Gozdnogospodarski Načrt Gozdnogospodarskega Območja Slovenj Gradec (2011-2020).

ZGS. (2019a). Poročilo Zavoda za gozdove Slovenije o gozdovih za leto 2018. Zavod za gozdove Slovenije.

ZGS. (2019b). Poročilo o delu Zavoda za gozdove Slovenije za leto 2018. Zavod za gozdove Slovenije.

Zhang, Q. H., \& Schlyter, F. (2010). Inhibition of predator attraction to Kairomones by non-host plant volatiles for herbivores: a bypass-trophic signal. PLoS One, 5(6), e11063. https://doi.org/10.1371/journ al.pone.0011063

Zuur, A., leno, E., Walker, N., Savelie, A., \& Smith, G. (2009). Mixed Effect Models and Extensions in Ecology with R. Springer Verlag.

How to cite this article: Šramel N, Kavčič A, Kolšek M, de Groot M. Estimating the most effective and economical pheromone for monitoring the European spruce bark beetle. J Appl Entomol. 2021;145:312-325. https://doi.org/10.1111/ jen.12853 